\title{
KRITIK TERHADAP KAPITALIS-PATRIARKIS DAN PERSPEKTIF SUBSISTENSI DALAM NOVEL AROMA KARSA KARYA DEWI LESTARI
}

\author{
Rasiah, Yana, dan Faika Burhan* \\ E-mail: rasiahfib@uho.ac.id \\ *Fakultas Ilmu Budaya Universitas Halu Oleo, Kendari
}

\begin{abstract}
Since capitalism-patriarchy is viewed as the specter of the problem of the emergence of injustice, it has been raising efforts to realize social justice and environmental sustainability through restructuring of the human mindset towards nature and fellow humans. The principle of capitalism-patriarchy has led to a culture of death and destruction because it is characterized by domination, power, exploitation, and environmental damage. This research sought to describe the criticism of patriarchal-capitalism and the subsistence perspective shown in the novel Aroma Karsa written by Dewi Lestari. Through ecofeminism proposed by Vandana Shiva and Mies, this study found that the power of the capitalistpatriarchal was represented through male figures such as; Jati Wesi, Khalil and Ferdi, who utilize nature and parts of women's bodies for financial interests and sexual desires through the production of the most expensive perfume, make certain plant species endangered and oppressed. Their cultivation efforts cannot be separated from profit orientation. The perspective of subsistence is then carried out by women characters to preserve, protect, and utilize natural resources as needed out of exaggeration. It is illustrated through female figures; Janirah, Raras, and Tanaya Suma who tried to stem the power and domination of men over nature and women's bodies for the benefit of capital. The subsistence perspective in the novel Aroma Karsa by Dewi Lestari emphasizes the preservation and protection of nature for the sake of mutual needs and comfort, and it is women who understand more about nature more than men.
\end{abstract}

\section{Record of Article}

Received : 10 Februari 2020

Revised : (minor)

Accepted : 30 Agustus 2020

Keywords: Subsistence, Capitalism-Patriarchy, Nature, Women, Ecofeminism 


\section{PENGANTAR}

Eksploitasi alam dan perempuan ditengarai bukan saja mengenai prilaku kesemena-menaan terhadap alam dan perempuan, tetapi lebih jauh menyangkut persoalan ideologis. Kerusakan alam dan eksploitasi perempuan, semisal prostitusi (Khaldirian, 2019) dan KDRT (Azizy, 2017) merupakan implikasi yang muncul dari "tandem absolut kapitalisme dan sistem patriarki" Alam dan perempuan telah menjadi komoditi yang mendatangkan profit dan dikontrol oleh dominasi guna membangun sekat ruang otoritas yang besar dan menyeluruh. Kapitalisme-patriarki selanjutnya dituduh sebagai dualitas musabab munculnya penindasan manusia (khususnya perempuan) dan alam.

Kapitalisme-patriarki sebagai dasar munculnya penindasan disebabkan oleh sistem nilai yang dianutnya. Menurut Shiva (1997) kapitalisme-patriarki memiliki prinsip pengutamaan profit setiap produksi yang harus menghasilkan laba dan memupuk modal setinggi-tingginya demi mendapatkan keuntungan yang masif. Ia juga mengembangkan prinsip maskulinitas yang di dalamnya, bercirikan dominasi, eksploitasi, dan penindasan, sehingga mengarah pada budaya kematian dan penghancuran. Prinsip yang dikembangkan kapitalisme-patriarki menurut Shiva (1997) mengarah kepada pemisahan manusia dengan alam lingkungan dan memungkinkan terjadinya penaklukan lingkungan oleh manusia. Alam dengan seluruh organisme yang terdapat di dalamnya dilihat sebagai objek dan sarana untuk memenuhi kepentingan manusia (laki-laki), sehingga tidak ada ikatan emosional antara alam dan manusia yang ada hanya relasi fungsional. Alam berfungsi untuk melayani manusia, dan manusia merasa memiliki hak absolut untuk mengeksploitasi alam, sebagaimana pandangan antroposentris berlaku. Bahwa pusat alam semesta adalah manusia sehingga kepentingan manusia paling menentukan dalam pengambilan kebijakan berkaitan dengan alam secara langsung maupun tidak (Evelyn \& Grim, 2003).

Novel Aroma Karsa (2018) merupakan novel yang menghadirkan persoalan alam dan perempuan yang dieksploitasi untuk kepentingan capital dan profit. Persoalan itu direpresentasikan melalui aktivitas produksi parfum yang mahal dengan aroma yang khas. Parfum tersebut diracik dengan bahan dasar tumbuhan bernama Puspa Karsa, yaitu tanaman Anggrek yang tumbuh liar dan langka di hutan Gunung Lawu dicampur dengan aroma tubuh perempuan. Tokoh laki-laki bernama Jati Wesi digambarkan memiliki ketajaman penciuman, sehingga mampu mengendus aroma tanaman Puspa Karsa untuk membuat parfum dan aroma tubuh seorang perempuan bernama Tanaya Suma untuk menuntaskan karyanya sebagai penyempurna formula parfum. Ia melakukan itu untuk menghasilkan produk parfum yang unik yang dapat bersaing dalam kontestasi pasar yang kian alot. Jati menyadari bahwa perpaduan wangi Puspa Karsa dan aroma tubuh perempuan akan membuat parfumnya semakin bersaing di dunia modern dibandingkan bahan buatan yang lebih banyak mengandung alkohol. Puspa Karsa dan aroma tubuh perempuan merupakan sumber kapital dan profit bagi 
Jati Wesi dalam memenangkan persaingan dalam bisnis parfum. Di sisi lain, tokoh perempuan lainnya seperti Janirah, Raras, dan Tanaya Suma berupaya untuk menemukan dan membudidayakan tanaman Puspa Karsa. Mereka tidak saja melindungi Puspa Karsa, tetapi juga membudidayakannya tanaman-tanaman lainnya untuk kampanye keindahan dan keasrian lingkungan, serta dapat menjadi obat penyembuh penyakit, sebagaimana Suma menggunakan tanaman itu untuk sembuh dari sakitnya.

Mengamati kegiatan tokoh laki-laki dan perempuan di atas, maka masalah yang muncul dalam tulisan ini adalah kuasa kapitalis-patriarkis dan subsistensi perempuan. Laki-laki merepresentasikan agen kapitalis patriarkis yang berupaya mengeksploitasi alam dan perempuan untuk kepentingan ekonomi. Sementara perempuan merupakan agen ekofeminis yang berupaya menjaga kelangsungan alam sekaligus manusia melalui budi daya tanaman Puspa karsa untuk kepentingan kehidupan. Fenomena ini berkaitan dengan istilah subsistensi dalam studi ekofeminis. Menurut Shiva dan Mies (2005: 353) subsistensi merupakan perspektif yang memiliki visi untuk menghentikan semua praktik dan sistem yang mengancam kelangsungan hidup. Visi ini mengenai masyarakat non-eksploitatif, masyarakat non-patriarkhi yang menghormati dan bukan menghancurkan alam. Ia berasal dari gerakan akar rumput, baik yang ada di negaranegara sedang berkembang atau tidak berkembang untuk mempertahankan kehidupan. Dalam mewujudkan visi ini, perempuan dipandang lebih banyak memahami bahwa perspektif subsistensi merupakan satu-satunya jaminan akan keberlangsungan hidup semua orang dan bukan integrasi ke dalam sistem pembangunan industri. Subsistensi kemudian dipandang langkah solutif untuk keluar dari paham kapitalisme patriarkis sebagai ideologi yang menindas perempuan dan bersikap eksploitatif terhadap alam. Pertanyaan kemudian adalah bagaimanakah kritik terhadap kapitalis-patriarkis dan perspektif subsistensi ini ditampilkan dalam novel Aroma Karsa karya Dewi Lestari? Pengungkapan kedua permasalahan tersebut dalam novel Aroma Karsa karya Dewi Lestari penting untuk menunjukkan bagaimana kapitalisme patriarkis beroperasi dalam kehidupan manusia yang sarat dengan penindasan, dan eksploitasi, yang kadangkala tidak disadari. Secara praktis, tulisan ini dapat menjadi rujukan bagi peneliti sastra berikutnya yang mengkaji persoalan yang sama.

Beberapa kajian sebelumnya yang membahas tentang kaitan alam dan perempuan yang merepresentasikan dalam sastra, seperti representasi alam dan perkebunan di Amerika bagian Selatan melalui novel Gone With The Wind (Rasiah, 2014), hanya saja pembahasannya lebih kepada pembahasan tentang lingkungan dan sastra secara umum. Demikian juga dengan film Marsha and the Bear, Rasiah (2015) lebih menyoroti edukasi mengenai hubungan manusia, alam, dan binatang. Edukasi ini kemudian dilanjutkan dengan gerakan nyata melalui penyadaran lingkungan kepada siswa menegah di Kota Kendari melalui penulisan eko-puisi (Rasiah, Masri, Arman, \& Iman, 2018). Secara spesifik, Vidiyanti (2016) menelaah novel Lemah Tanjung karya Ratna Indraswari Ibrahim melalui perspektif ekofeminisme Vandana Shiva dengan mengidentifikasi kapitalisme patriarki sebagai sumber kerusakan alam. Meskipun begitu, Vidiyanti tidak mengulas masalah subsistensi sebagai wujud solusi yang 
ditawarkan oleh ekofeminisme Shiva dan Mies. Wuriyani, Udasmoro, dan Simatupang (2017) mengkaji negosiasi mitos hubungan perempuan dengan alam dalam Teks Opera Batak Perempuan di Pinggir Danau Karya Lerna Simanjuntak juga dengan perspektif yang sama. Secara khusus kajian tentang Aroma Karsa sendiri telah dilakukan oleh Anisa (2018) yang membahas representasi mitologi Gunung Lawu dalam novel Aroma Karsa karya Dewi Lestari dengan menggunakan perspektif Antropologi sastra. Sejumlah pembahasan yang telah disebutkan ini, belum ada pembahasan yang spesifik perihal kritik terhadap kapitalisme-patriarki yang telah menjadi momok penindasan terhadap alam dan perempuan, serta tawaran solusi berupa perspektif subsistensi. Padahal masalah ini penting karena permasalahan kerusakan lingkungan dan penindasan terhadap perempuan bukan persoalan prilaku saja, tetapi lebih jauh mengakar pada ideologi yang telah membentuk pola pikir manusia. Jadi, artikel ini mengisi kekosongan tersebut dalam penelitian sastra, khususnya yang menggunakan ekofeminisme.

\section{ECOFEMINISME VANDANA SHIVA DAN MARIA MIES}

Feminisme melihat bahwa persoalan perempuan kian kompleks. Ia tidak saja berhadapan dengan isu-isu ketidaksetaraan, tetapi juga dibenturkan oleh isu-isu fundamental berkaitan dengan kelangsungan hidup dan pemeliharaan kehidupan di planet ini, bukan hanya persoalan perempuan, anak-anak, dan umat manusia pada umumnya, tetapi juga berkaitan dengan semakin hancur dan langkahnya flora dan fauna. Shiva dan Mies (2005: 3) menuding penyebab dari degradasi bumi adalah projek modernisasi, pembangunan, dan pengembangannya. Sistem yang dibangun dan dijalankan saat ini lewat penindasan terhadap perempuan dan penjajahan terhadap orang-orang "asing' dan tanah air mereka; dan bagi alam, hal ini akan semakin menimbulkan kerusakan.

\section{Kritik Shiva terhadap Pemikiran Kapitalisme-Patriarki}

Ketidakadilan sosial dan kerusakan lingkungan menurut Vandana Shiva dan Mies merupakan implikasi dari kapitalisme-patriarki. Keduanya merupakan dualitas dalam satu tubuh penindasan manusia (Khaldirian, 2019). Menurut Khaldirian, kapitalisme menjalankan perannya sebagai penggerak roda finansial berorientasi profit. Di lain pihak, patriarki menjalankan fungsi kontrol dominan, hukum dan aturan dalam rangka membangun sekat ruang otoritas yang masif dan totaliter. Shiva dan Mies (2005) berpendapat bahwa segala usaha untuk mewujudkan kelestarian lingkungan dan keadilan sosial tidak akan membuahkan hasil yang signifikan apabila tidak diikuti dengan langkah-langkah konkrit untuk menghapuskan cara pandang dan pola pikir kapitalisme-patriarki. Hal ini disebabkan sistem nilai yang dikembangkannya kurang peduli terhadap kelestarian lingkungan, dan tidak memberikan tempat yang wajar dan bahkan cenderung menindas kaum perempuan. Landasan epistemologi yang dikembangkan oleh kapitalisme-patriarki dikritisi oleh Shiva dan Mies karena 
cenderung memisahkan manusia dengan lingkungan dan memungkinkan terjadinya penaklukan lingkungan oleh manusia. Hutan dengan seluruh organisme yang terdapat di dalamnya hanya dapat dilihat hanya objek dan sarana untuk memenuhi kepentingan manusia, sehingga tidak ada ikatan emosional antara hutan dan manusia yang ada hanya relasi fungsional.

Shiva dan Mies (2005: 120) kemudian memiliki konsep perjuangan untuk mewujudkan keadilan sosial dan kelestarian lingkungan yakni dengan penataan kembali pola pikir manusia terhadap alam maupun sesama manusia. Visi dasar dari landasan ontologi yang dikembangkanya adalah menempatkan kedudukan manusia sebagai makhluk yang relasional, yang saling memperkaya saling melengkapi dan saling membutuhkan satu dengan lainnya. Konsep ini sekaligus mengkritik sistem kapitelisme-patriarki yang menempatkan manusia sebagai makhluk penguasa dan penjajah terhadap alam maupun perempuan. Visi epistemologi berlandaskan pada tanggung jawab kultural untuk merombak penindasan menuju pembebasan kemudian dikembangkan oleh ekofeminisme yang digagas oleh Vandana Shiva dan Mies yang kemudian dikenal dengan ekofeminisme sosial transformatif. Segala bentuk pengetahuan yang bersifat patriarki harus diganti dengan pengetahuan yang lebih berkeadilan gender dan ekologis dengan cara menjadikan nilai-nilai feminisme sebagai visi dasar pengembangan epistemologi. Nilai-nilai feminitas seperti memelihara, merawat, cinta, dan lainnya dijadikan landasan bagi epistemologinya. Penempatan prinsip-prinsip feminitas dalam pengembangan pengetahuan menurut pandangan Shiva (Suliantoro, 2013) dapat menciptakan ilmu yang lebih ramah lingkungan dan berkeadilan gender.

\section{Ekofeminisme: Perspektif Subsistensi, Kebutuhan Akan Visi Baru}

Perspektif subsistensi merupakan bagian dari teori ekofeminis sosialis transformatif yang dikembangkan oleh Vandana Shiva dan Maria Mies sebagai solusi dari epistemologi kapitalisme patriarki. Melalui perspektif ini, Shiva dan Mies mengajak masyarakat untuk menyadari dan menerima 'kealamian' fisikalitas dan materialitas manusia (Tong, 2010: 395). Menurut mereka, alam adalah barang yang akan habis, sehingga manusia harus belajar menghematnya dengan hidup sesederhana mungkin, dan mengkonsumsi sesedikit mungkin. Solusi yang ditawarkan oleh Shiva dan Mies adalah perspektif subsistensi jika manusia peduli terhadap kehidupan generasi manusia di masa yang akan datang.

Kata subsistensi berasal dari bahasa Latin, subsistere yang berarti; bertahan, menghentikan, tetap melakukan, melawan, mundur ke belakang, mempertahankan dan keterbelakangan. Sedangkan kondisi subsistensi secara umum diartikan sebagai cara hidup yang cenderung minimalis dengan melakukan usaha-usaha bertujuan untuk sekedar hidup (Rahardjo, 1999). Namun, perspektif subsistensi dalam teori ekofeminisme merupakan kunci untuk menghentikan semua praktik dan sistem yang mengancam kelangsungan hidup. Visi baru mengenai masyarakat non-eksploitatif, masyarakat non-patriarkhi yang menghormati dan bukan menghancurkan alam, ialah 
berasal dari gerakan akar rumput, baik yang ada di negara-negara sedang berkembang atau tidak berkembang untuk mempertahankan kehidupan. Dalam mewujudkan gerakan ini, Shiva menuturkan bahwa perempuanlah yang lebih banyak memahami bahwa perspektif subsistence merupakan satu-satunya jaminan akan keberlangsungan hidup semua orang dan bukan integrasi ke dalam sistem pembangunan industri (Shiva dan Mies, 2005: 353).

Munculnya perspektif subsistensi dipicu oleh munculnya konflik antara perspektif pasar dan perspektif uang yang kerapkali menjadi sumber konflik antara laki-laki dan perempuan. Kedua perspektif tersebut merupakan sumber kapitalis patriarki. Hal ini menurut Shiva dan Mies (2005) dikarenakan perempuan terlibat dalam pemeliharaan hutan dan berkeinginan untuk memelihara basis mata pencaharian mereka, sementara kaum laki-laki menginginkan modernisasi kerja upahan. Shiva dan Mies (2005: 370-372) menjabarkan bahwa perspektif subsistence tersebut kemudian dikembangkan dengan landasan prinsip-prinsip sebagai berikut.

1. Tujuan dari kegiatan ekonomi bukanlah untuk menghasilkan timbunan upah atau keuntungan bagi pasar yang tak jelas, tetapi untuk melahirkan dan menghasilkan kembali kehidupan.

2. Kegiatan ekonomi didasarkan pada relasi baru:

a. Menjaga dan melestarikan alam dalam hal keanekaragamanya

b. Membangun relasi yang harmonis antara manusia dengan alam dengan cara tidak mengeksploitasi dan menindas perempuan demi membangun kesetaraan gender.

3. Menciptakan kembali integritas antara kebudayaan dan kerja

\section{METODE PENELITIAN}

Penelitian ini merupakan jenis penelitian kepustakaan dengan metode deskriptif kualitatif. Data dalam penelitian ini adalah teks novel Aroma Karsa karya Dewi Lestari yang diterbitkan oleh Benteng Pustaka pada bulan Maret 2018. Data diambil dari dialog tokoh-tokoh, penggambaran peristiwa, latar, maupun unsur lainnya yang muncul di dalam novel yang memungkinkan untuk dimaknai. Data dalam penelitian ini selanjutnya dianalisis secara deskriptif-interpretatif. Deskriptif interpretatif adalah menganalisis secara detail terhadap data yang dikumpulkan kemudian melakukan penafsiran terhadap data yang telah diperoleh dengan menggunakan pendekatan teori ekofeminis sebagaimana yang telah disebutkan di atas.

\section{HASIL DAN PEMBAHASAN}

\section{Kritik Terhadap Kuasa Kapitalis Patriarki Dalam Novel Aroma Karsa}

Kritik terhadap kapitalisme-patriarki di dalam novel Aroma Karsa karya Dewi Lestari direpresentasikan melalui kegiatan eksploitatif dan oportunis yang dilakukan oleh tokoh Jati Wesi. Jati Wesi merupakan tokoh maskulin yang memiliki usaha parfum yang 
memanfaatkan tanaman anggek liar dan langka, salah satunya bernama Puspa Karsa. Puspa Karsa hidup di belantara pegunungan Lawu dan sangat langka. Jati wesi digambarkan memiliki indra penciuman yang tajam, sehingga ia mampu membaui aroma anggrek puspa karsa dan aroma tanaman langka lainnya untuk kemudian diramu sebagai bahan parfum. Karakterisasi tokoh Jati Wesi dapat dicermati dalam kutipan berikut.

Badai telah sengaja merembeskan aroma dan membiarkan sekelumit rahasia kedatangannya terungkap. Jati melihat sekeliling seraya menggosok ujung hidungnya yang bertambah gatal. Ia yakin ada makhluk lain yang menangkap pertanda serupa, yang memilih tidak terkecoh terik matahari dan bersahabatnya kesiur angina. Makhluk yang sudah pasti bukan manusia (Lestari, 2018: 24).

Kutipan di atas menjelaskan Jati Wesi yang memiliki kepekaan penciuman di atas standar manusia. Ia setara dengan makhluk yang menjadikan indra penciuman sebagai sarana navigasi hidup, entah mencari makanan, atau mengendus bahaya, semisal tikus. Di dalam novel diceritakan bahwa kemampuan Jati Wesi dalam membaui aroma tanaman menjadikan dia mampu mengidentifikasi tanaman apa yang dapat menjadi bahan dasar pembuatan parfum terbaik. Di situlah ia menemukan tanaman bunga Puspa karsa, sebuah tanaman bunga anggrek yang langka dan tumbuh di hutan liar Gunung Lawu. Hidung Jati yang peka mampu memahami bahwa ketika tanaman diolah dalam bidang industri sebagai formula parfum dapat menghasilkan kapital setinggi-tingginya. Nilai kapital yang tinggi merupakan impian Jati Wesi selama ini. Indra penciuman di sini dapat dimaknai sebagai kemampuan dasar laki-laki yang kemudian digunakan untuk eksploitasi alam. Jati Wesi dapat dimaknai sebagai representasi kapitalis.

Puspa Karsa dalam novel Aroma Karsa dimitoskan sebagai tanaman ajaib dan menyerupai karakter perempuan. Ia tidak saja memiliki kekuatan aroma yang membangkitkan gairah tetapi juga mendatangkan kekuatan dan kekuasaan bahkan kerusakan. Di dalam novel Puspa Karsa dituliskan sebagai berikut:

Wangi lezat memenuhi udara, memenuhi hidung dan rongga dadanya. Wangi itu baru bagi penciumannya, dan seketika terasa akrab. Suma berasa pulang ke sebuah rahim, mengapung dalam rasa aman dan nyaman. Kenikmatan yang Suma rasakan semakin sensual. Wangi yang tidak hanya berhenti di penciumannya, tapi juga membelai kulitnya, bergulung di lidahnya, mengalun di telinganya, dan matanya menangkap kerlap kerlip emas bagai dansa seribu kunang-kunang di langit malam...keindahan itu tak terperi. Batinnya ikut menjeritkan ketidakadilan bagaimana mungkin keajaiban semacam ini dikurung dalam kegelapan? (Lestari, 2018: 639-640)

Deskripsi karakter Puspa Karsa dalam kutipan di atas mengindikasikan bahwa Puspa merupakan tumbuhan eksotis yang memiliki daya pikat tinggi layaknya seorang Rasiah, Yana, dan Faika Burhan, Perspektif Subsistensi dalam Novel Aroma Karsa ... । 168 
perempuan. Daya pikat itu terletak pada aromanya yang khas yang mampu membawa kenyamanan bahwa sensualitas pada orang yang mengendusnya. Daya pikat inilah yang kemudian membuat para kapitalis berburu untuk mendapatkannya. Ia dipandang menguntungkan dalam dunia industri.

Karakter Puspa Karsa sebagai simbol perempuan diperkuat dengan sepenggal cerita di masa lalu yang ditampilkan dalam novel. Puspa Karsa dimitoskan sebagai seorang perempuan titisan Dewa yang memiliki kecantikan sekaligus memberikan dampak yang luar biasa bagi yang memperistrinya. Ia dapat mendatangkan anugerah sekaligus kehancuran tergantung bagaimana ia diperlakukan. Berikut kutipannya.

Pada mulanya, kehidupan Puspa Karsa membaik setelah diperistri Mahesa Guning. Ia hidup nyaman, sohor, kaya raya dan dianugrahi keturunan yang hebat-hebat. Mahesa Guning bahkan berhasil menjadi orang nomor satu di Majapahit. Menyadari kekuatan Aroma Puspa Karsa atas manusia, mulai timbul sifat serakah Mahesa Guning. Ia memanfaatkan aroma dan daya pikat Puspa Karsa untuk memperoleh segala ambisi dan keinginannya. Mulai timbul kekacauan di mana-mana. Kehidupan mereka dikelilingi pengkhianatan. Kedamaian berangsur hilang (Lestari, 2018: 420-421).

Mahesa Ganing merupakan representasi kapitalis-patriarkis yang muncul di masa lalu. Ia mengeksploitasi dan memanfaatkan Puspa Karsa sebagai seorang perempuan untuk mendapatkan keuntungan pribadi. Puspa Karsa dihadirkan sebagai objek yang tertindas yang menandai simbol eksploitasi dan penindasan terhadap alam dan perempuan. Eksploitasi Puspa Karsa yang berlebihan kemudian membawa kepada kekacauan dan kehancuran. Hal ini menandai eksploitasi alam dan alam yang berlebihan akan menimbulkan ketidakseimbangan yang pada akhirnya dapat menimbulkan bencana di mana-mana. Pengandaian bunga-bunga sebagai perempuan dan perlakuan atas dirinya dapat dilihat dalam kutipan berikut.

Sesaat Jati terbang dari kantor polisi di Bekasi dan mendarat di sebuah rimba tropis, menyibak hijaunya dedaunan yang bergantung di batangbatang kayu bersama benderangnya oranye jeruk neroli. Dibalik itu, Jati melihat wajah-wajah mungil phalenopisis javanica yang bercak kemerahan dengan bibir ungu menantang. Mereka menggempurnya dengan aroma manis yang kompleks, seperti lima macam kembang dijadikan satu. Ada jejak rempah. Ada unsur rerumputan. Ada sedikit kecut limau. Semua kompleksitas yang indah itu lantas diikat oleh kesturi berkualitas tinggi yang selama ini hanya bisa diimpikan oleh Jati (Lestari, 2018: 61).

Sejak awal peradaban manusia, sistem patriarki telah membangun pembagian struktur hierarki dalam rumah tangga dan kemudian berimbas pada kehidupan bermasyarakat di era modern. Sistem ini telah meletakan pseudo-boundary (Khaldirian, 2019). Laki-laki memiliki legitimasi superioritas sedangkan perempuan tersingkir 
sebagai subjek subordinat. Kondisi demikian secara kultur historis mengalami transfer secara terus menerus dan turun temurun, yang pada akhirnya dianggap sebagai sebuah bentuk keterberian yang disakralkan. Di sinilah struktur dominasi terbangun yang tanpa sadar terintegrasi menjadi dominasi sistemik inter-gender yang menempati ruang-ruang politik dan ekonomi, dan bukan lagi sekadar urusan rumah tangga ataupun batasan biologis berdasarkan jenis kelamin. Kondisi ini juga ikut membentuk pola pikir terhadap alam. Anggapan bumi itu seperti perempuan menjadikan agen-agen kapitalis-patriarkis merasa memiliki hak untuk mengeksploitasinya.

Mengolah sumber alam untuk kepentingan manusia sesungguhnya bukan masalah. Yang menjadi masalah adalah ketika manusia mulai mengeksploitasi sumber daya alam tersebut untuk mendapatkan keuntungan sebesar-besarnya. Sumber daya alam terancam habis dan generasi masa depan menjadi terancam. Inilah yang dipersoalkan oleh ekofeminist seperti Shiva dan Mies. Pengeksploitasian alam yang tak terkendali akan membawa kehancuran dn kepunahan spesies tertentu sehingga tidak saja mengancam keseimbangan alam tapi juga warisan kehidupan untuk anak cucu.

Dalam novel Aroma Karsa digambarkan bahwa permintaan pasar terhadap parfum yang diracik dengan bunga-bungan angrek liar, menjadikan tokoh-tokoh seperti Jati Wesi berupaya untuk mendapatkan bunga tersebut sebesar-besarnya, seperti yang tampak dalam kutipan berikut.

Bertahun-tahun Jati membuat dan mengumpulkan ekstrak. Memesan bibit siap pakai sering kali tidak memuaskannya. Belum lagi jika aroma yang ia inginkan tidak dijual di pasaran. Dalam alkohol 99\%, Jati akhirnya memeram sendiri bermacam-macam hal. Mulai dari yang lazim seperti jintan, kembang lawang, merica butir, kayu manis, ilalang kering, hingga yang tak lazim seperti kerak beras, arang, bubuk cacing, cangkang kumbang. Dan rumah semut.

Selama Jati tetap menjalankan tugasnya sebagai penyempurna formula parfum, Khalil dan rekan-rekannya ikhlas memberikan ruang pada kegilaan dalam Lab sinting. Mereka tahu keliaran Jati membuat formula parfum yang menurut mereka luar biasa, tetapi sampai kapan pun Attarwala tidak sanggup memodali kreativitas Jati. Di toko kecil itu, semua memahami bahwa mengimitasi merek terkenal merupakan satu-satunya jalan untuk bertahan" (Lestari, 2018: 191-192).

Kutipan di atas menegaskan bahwa pasar telah mengubah menusia menjadi eksploitatif. Semuanya demi mengejar keuntungan dan kemapanan ekonomi. Persaingan pasar membuat manusia mencari pemenuhan dengan jalan mengeksploitasi alam untuk kepentingan laba sebesar-besarnya. Beginilah cara kapitalisme bekerja. Cara Jati Wesi dalam dan usaha parfum bernama Attawal merupakan cerminan kapitalisme. Seperti yang dikatakan oleh Shiva (1997: 53) bahwa hutan dengan seluruh organisme yang terdapat di dalamnya hanya dapat dilihat sebagai objek dan sarana untuk memenuhi kepentingan manusia, sehingga tidak ada ikatan emosional antara alam dan manusia, yang ada hanya relasi fungsional. Hutan dan semua isinya hanya berfungsi 
untuk memenuhi kebutuhan manusia terutama untuk mencapai kepuasan tersier. Sebagaimana ditunjukkan dalam kutipan berikut.

Dengan tangan terlipat di depan dada, Iwan melihat sekeliling. Cuma aku sendiri yang merasa, apa gimana? katanya lantang. Kalau lokasi tanaman super ini adanya di pulau terpencil mana, kek, yang masih ada hutan perawannya, saya mungkin masih bisa terima. Gunung Lawu? Tempat itu sudah kaya pasar malam! Apa lagi yang bersembunyi di situ? Sudah habis diubrak-abrik pendaki gunung dan orang-orang pesugihan (Lestari, 2018: 426).

Kutipan di atas menegaskan dampak industri dan ambisi manusia untuk mendapatkan keuntungan sebesar besarnya telah berakibat pada kehancuran alam beserta habitat makluk hidup di dalamnya.

Novel Aroma Karsa, juga menggambarkan bahwa racikan parfum yang dikembangkan oleh toko parfum Attawala adalah dengan menggunakan aroma tubuh perempuan, yakni cairan Miss V. Jati Wesi yang terkenal dengan kepekaan indra penciuman yang di atas rata-rata manusia, menemukan formula baru mengenai racikan parfum, yakni tambahan aroma tubuh perempuan untuk meningkatkan gairah seksual pemakai parfum. Jati Wesi kemudian menyimpulkan bahwa cairan Miss V, dan aroma keringat yang bisa meningkatkan gairah untuk berhubungan intim, sehingga akan memberi pengaruh kepada gairah seksual jika diracik sedemikian rupa dengan bahan parfum lainnya, seperti bunga Puspa Karsa. Tokoh perempuan bernama Tanaya Suma kemudian menjadi targetnya.

Selesai menutup pintu kamar Suma, Jati berjalan cepat meninggalkan rumah utama, lalu berlari sekencang-kencangnya mulai dari teras menuju olfaktorium. Otaknya dipenuhi oleh gambaran tingtur yang akan ia pilih. Tanganya mengepal, menahan ingatan aroma Suma agar tidak melincir keluar. Terengah ia mengambil botol-botol tingtur dengan kalap. Di dalam bangunan menyerupai kotak kaca itu, Jati menuntaskan kreasinya. Kangga dengan formula dua lapis. Formula pertama Kangga adalah racikan yang akan mengungkap kombinasi lima jenis mawar-mawar Damaskus, Alba, sentifolia, the, dan mawar kesturi, lalu dijalin dengan manisnya aroma jambu, ceri hitam, kembang semak kupu-kupu, kembang tobira, lantas disuntik kesegaran aras, basil, bergamot, daun melisa, daun spearmint, dan dihangatkan lada jambon, kayu masoi, caramel gula kelapa. Semua itu kemudian diikat akar tiga macam kesturi, arris, serta ambergis. Sementara formula lapis keduanya yaitu, sebuah kombinasi selembut kepala susu, selunak mentega semenarik pertemuan unik antara kesegaran alang-alang dan kehangatan vanili. Itulah aroma DNA yang akan Jati selipkan setiap rangkaian Puspa Ananta. Formula yang akan memancing desah siapa pun yang membauinya (Lestari, 2018: 395-396). 
Tindakan Jati yang memanfaatkan bagian dari tubuh perempuan untuk mendapatkan keuntungan komersil dan pemuasan hasrat seksual laki-laki merupakan gambaran yang jelas tentang prilaku kapitalis-patriarki. Kapitalis-patriarki menjadikan tubuh perempuan sebagai target akhir yang dijadikan sebagai objek untuk diekploitasi sekaligus ditindas.

Alam dan perempuan dalam pandangan kapitalis-patriarki merupakan komoditi yang menguntungkan. Menurut Shiva dan Mies (2005: 156) pandangan laki-laki yang terpusat pada tubuh perempuan merupakan salah satu pemuas hasrat seksualnya, seperti halnya keinginan terhadap alam. Keinginan terhadap tubuh perempuan yang telanjang merupakan kesenangan bagi laki-laki. Hasrat tersebut, tidak hanya dilakukan dengan interaksi terhadap orang yang hidup tetapi oleh respon terhadap benda-benda mati sekalipun. Ramuan parfum yang mencampurkan berbagai jenis bunga dan rempah dengan aroma tubuh perempuan mengarah kepada pembangkit gairah seksual terutama laki-laki. Menurut Zucker (2019) aroma yang dirasakan oleh indra penciuman seseorang berkaitan erat dengan kepuasan seksual seseorang. Dalam melakukan kegiatan seksual, seseorang bisa merasakan rangsangan tidak hanya dari sentuhan saja, tetapi dari visual maupun bau. Kepekaan indera penciuman nyatanya bisa menambah gairah seksual. Jati Wesi yang menempatkan diri sebagai sang maskulin yang menguasai perempuan dan alam. Jati melampiaskan hasratnya bukan hanya pada tubuh Tanaya Suma, tetapi juga melalui aroma bunga-bunga langka dan rempah. Perpaduan antara DNA perempuan dan beberapa tanaman tersebut, menunjukkan adanya hubungan perempuan dan alam yang dihadirkan sebagai objek yang tertindas oleh kekuasaan kapitalisme patriarki. Itulah mengapa perempuan sering dijadikan sumber komoditi yang menguntungkan seperti yang terlihat dalam iklan-iklan produk.

\section{Perspektif Subsistensi dalam Novel Aroma Karsa}

Seperti yang sudah diuraikan pada poin teori, bahwa subsistensi dalam pandangan ekofeminisme adalah sebuah gerakan yang mengarah kepada penghentian semua praktik eksploitatif, patriarkis, dan menghancurkan alam. Dalam novel Aroma Karsa perspektif subsistensi direpresentasikan melalui tokoh-tokoh perempuan dengan mengubah visi baru tentang alam, ekonomi, dan relasi laki-laki dan perempuan. Tokohtokoh seperti Janirah, Raras, dan Tanaya Suma merupakan pembawa visi baru gerakan subsistensi tersebut dengan cara masing-masing.

Janirah ditampilkan sebagai tokoh perempuan yang memberikan perhatian terhadap alam dengan dengan cara melindungi tanaman Puspa Karsa dari jangkauan orang-orang serakah. Janirah digambarkan sudah mengetahui keberadaan Puspa Karsa sejak ia mengambil dokumen di Kraton Yogyakarta, ketika ia masih menjadi abdi dalam di Kraton tersebut.

Kelopak Mata neneknya membuka dan bibirnya melepas senyum lemah. "Puspa Karsa", ucapannya. Suara itu parau, tetapi tidak lesu. Kilau di matanya bahkan menandakan sebuah cerita besar akan bergulir. Raras mengenali semua gelagat 
itu dengan baik. Ritual yang berjalan sejak Raras masih kecil. Eyang putri mendongengkan bermacam ragam kisah memikat, fiksi maupun fakta. Aku ini pencuri, ucap neneknya kerap kali. Pencuri yang membagikan faedah bagi orang banyak (Lestari, 2018: 2).

Puspa Karsa merupakan tanaman yang memiliki legenda di era kerajaan Majapahit. Ia merupakan transformasi dari seorang perempuan yang dibunuh dan kemudian darahnya menjelma menjadi sekuntum bunga anggrek yang memiliki bau sensual memikat nadi. Keberadaannya pun menjadi misterius. Karena daya pikatnya tersebut, ia diburu oleh para pengemban modal di bidang industri maupun pengejar kekuasaan. Janirah kemudian bertindak untuk melindungi bunga tersebut dari jangkauan orang yang tidak bertanggungjawab. Janirah yakin di tangan seorang perempuan Pusa Karsa akan terlindungi dari gangguan orang-orang yang akan mengambil tanaman tersebut. Janirah adalah eyang putri Raras yang diceritakan melindungi bunga tersebut "Bunga yang sangat dirahasiakan wujudnya dan tempat tumbuhnya" (Lestari, 2018: 10).

Janirah yang memiliki hobi mengoleksi anggrek hanya mengisahkan Puspa Karsa kepada cucunya Raras Prayagung. Janirah ingin menyampaikan bahwa demi keselamatan tanaman tersebut membutuhkan peran perempuan untuk melindunginya dari tangan-tangan manusia yang serakah, dalam hal ini laki-laki. Bahkan ia berupaya menularkan ide kecintaan lingkungan kepada masyarakat lainnya, dengan cara mengembangbiakkan dan mengoleksi anggrek lainnya secara sukarela. Perspektif subsistensi ditunjukkan oleh Janirah, dimana Janirah memahami bahwa Puspa Karsa adalah tanaman yang langka yang harus dilindungi demi kelangsungan hidup tanaman tersebut. Di sisi lain hobinya dalam mengoleksi anggrek dengan tidak memburu keuntungan ekonomi, menunjukkan bahwa gerakan yang dilakukannya adalah noneksploitatif, tetapi lebih kepada menciptakan kehidupan. Sifat feminin yang melekat pada tokoh Janirah yaitu melahirkan, merawat, memberikan kasih sayang, dan kelembutan sangat relevan dengan upaya dirinya dalam melestarikan dan memelihara anggrek. Cara tersebut adalah merupakan salah satu upaya untuk melestarikan lingkungan. Hal ini dapat dilihat pada kutipan berikut.

Janirah adalah salah satu kolektor anggrek yang disegani, baik karena koleksinya maupun kegigihannya mengoleksi. Yang paling mengesankan bagi Raras adalah kemampuan Janirah menulari orang-orang dengan kecintaannya pada anggrek. Neneknya sering dengan sengaja mengirimkan tanaman anggrek dua-tiga kali bahkan lebih dari sepuluh kali, sampai orang yang dikirimi lama-lama ikut mengoleksi. Janirah melakukannya sebagai sebuah misi (Lestari, 2018: 18).

Selain Janirah, Raras juga merupakan salah satu tokoh perempuan yang berusaha melindungi alam meskipun ia juga sesungguhnya pelaku industri. Salah satu sifat kepedulian Raras terhadap alam yaitu tetap menjaga kealamian yang berasal dari alam dengan cara mengembangkan dan merawatnya. 
Raras menghirup udara di kamarnya dalam-dalam. Sama seperti neneknya dahulu, ia menyebar bokor-bokor kuningan berisi melati dan menjenuhkan barangbarangnya dengan aroma bola-bola cendana" "Empat puluh tahun telah silam dari momen terakhirnya dengan Janirah. Babak Puspa Karsa sudah pernah ia istirahatkan dan kini ia siap memulai babak baru (Lestari, 2018: 23).

Kutipan di atas menggambarkan bahwa Raras mewarisi kebiasaan Janirah dalam memanfaatkan sumber daya alam untuk kehidupannya, seperti bunga melati dan cendana untuk kebutuhan wewangian dalam rumah, obat-obatan dan keindahan rumah. Raras digambarkan memiliki sikap yang gesit, pintar, dan pekerja keras. Ia memulihkan kembali perusahaan yang bernama Kemara, perusahaan Jamu dan Kosemtik, yang sudah "sakit" dan berada di ujung kehancuran akibat ulah ayahnya bernama Romo. Hidup di dunia modern yang berlandaskan ilmu pengetahuan, Raras digambarkan berpikiran maju dan visioner. Ia tidak melupakan nasehat orang tetua dulu mengenai kebijaksanaan terhadap alam, juga tidak menafikan dunia ilmu pengetahuan dan teknologi. Hal ini tergambar dari cara Raras melanjutkan kebiasaan neneknya dalam merawat alam juga bekerja sama dengan seorang professor untuk sebuah ekspedisi Puspa Karsa. Eskpedisi tersebut diperlukan untuk eskavasi atau sekedar pembuktian ilmiah mengenai keberadaan Puspa Karsa yang melegenda tersebut.

"pertama-tama saya ucapkan terima kasih kepada Mbak Raras yang sudah mengumpulkan kita di sini dan meberikan dukungan penuh kepada projek ekspedisi Puspa Karsa" Lambang membuka pertemuan mereka layaknya pejabat pemerintah memulai rapat." Mohon izin, Mbak Raras. Kalau memang anggota Tim sudah lengkap saya akan memulai presentasi saya.

"Silahkan Mas," Raras menyahut.

Kutipan di atas mengindikasikan bahwa Raras sebagai tokoh perempuan mengadakan projek eskpedisi Puspa Karsa merepresentasikan visi bahwa kegiatan ekonomi bukanlah untuk menghasilkan timbunan uang atau keuntungan pasar yang tak jelas, tetapi untuk melahirkan dan menghasilkan kembali kehidupan. Puspa Karsa digambarkan sebagai bunga langka dan penuh legenda serta diburu banyak orang, sehingga Raras berinisiatif untuk menemukan dan membuktikan keberadaan itu secara ilmiah. Di pihak lain, ia mempromosikan relasi kerja yang tidak timpang antara laki-laki dan perempuan. Kegiatan ekonomi didasarkan pada relasi baru, yakni menjaga dan melestarikan alam dalam hal keanekaragamanya dan membangun relasi yang harmonis antara manusia dengan alam dengan cara tidak mengeksploitasi dan menindas perempuan demi membangun kesetaraan gender. Sosok Raras digambarkan dalam kutipan berikut.

Melewati rumah kaca dan kolam renang itu, ada jalur setapak lain. Jalur itu menghubungkan rumah utama kebangunan mungil berpagar pohon bungur. Dedaunan pohon-pohon itu rontok berebahan di tanah, memberi ruang tumbuh 
pada bunga yang melompok-lompok bagai bola-bola kertas merah jambu. Bagi kebanyakan orang, bunga bungur tidak mengeluarkan wangi yang kentara, bahkan menganggap bunga bugur sama sekali tidak wangi. Tidak bagi Jati. Apalagi dalam jumlah sebanyak itu. "Itu bangunan apa, Mbok?" Tanya Jati. “Tempat kerjanya Ibu.

Bagai akar beringin yang ditancapkannya, Kemara menjalar luas dalam waktu singkat. Berdirilah kompleks besar yang terdiri atas pabrik, kantor, gudang, sampai akhirnya seluruh area itu dianggap layak dinamai Kemara. Tak jauh dari sana keluarga Prayagung membeli satu bukit hijau dengan danau buatan untuk dijadikan kediaman. Masyarakat menamai bukit itu Bukit Kemara. "Raras Prayagung disebut-sebut sebagai Srikandi modern, Kartini Masa Kini, dan julukan-julukan superior lainnya. Tak Cuma sekali ia dibidik pemerintah untuk menjabat menteri kabinet, tetapi Raras masih menolak dengan pertimbangan ingin memajukan Kemara hingga ke titik ia siap menyerahkan tongkat estafet berikut adalah di tangan Tanaya Suma, putri tunggalnya (Lestari, 2018: 127,197).

Peran Raras terhadap lingkungan yaitu membangun bukit hijau atau Kemara. Kemara adalah sumber kehidupan bagi Raras. Raras menginginkan Kemara tetap terjaga hingga ia siap menyerahkannya pada Tanaya Suma. Dalam perspektif subsistensi manusia juga berusaha saling memperkaya dan juga harus tetap memperhatikan ekologi. Raras salah satu pelaku perspektif subsistensi dengan perannya yaitu mampu menciptakan hubungan manusia dan lingkungannya secara seimbang. Akan tetapi, di akhir cerita tokoh Raras dimatikan dengan cara diracuni oleh anaknya sendiri karena alas an kejujuran. Namun kematian Raras dalam novel ini dimaknai sebagai ketidaksetujuan pengarang atas rasa ingin tahu Raras yang berdampak pada ambisinya yang luar biasa, sehingga ia mengorbankan banyak uang dan manusia untuk memenuhinya. Tindakan seperti ini sudah mengarah pada tindakan eksploitatif.

Tokoh berikutnya yang dihadirkan sebagai representasi prilaku subsistensi adalah Tanaya Suma. Ia adalah anak angkat Raras Prayagung sebagai penerus Kemara. Suma merupakan perwujudan dari visi kegiatan ekonomi bukanlah untuk menghasilkan timbunan upah atau keuntungan bagi pasar yang tak jelas tetapi untuk melahirkan dan menghasilkan kembali kehidupan. Meskipun ia ikut dalam ekspedisi Puspa Karsa, ia tidak memiliki tujuan eksploitatif yang menguntungkan dirinya apalagi finansial, seperti ditunjukkan dalam kutipan berikut:

"Bukannya dari kecil kamu pengin cari Puspa Karsa?" Justru itu..." mata Suma mengerjap-ngerjap seolah berusaha melihat sesuatu yang buram di depan sana. "Aku tidak tahu kenapa bisa tanaman seperti itu penting? Padahal, kalau kupikir-pikir lagi, aku tidak punya kepentingan apaapa" (Lestari, 2018: 432). 
Perjalanan Suma ke hutan merupakan simbol pembebasan dirinya dari segala macam ikatan dan penindasan. Kekuatan yang muncul di dalam diri Suma dirasakan sebagai dorongan yang berasal dari alam sebagai simbol hubungan ibu dengan anak. Hal ini menunjukkan upaya perempuan untuk kembali ke dalam dirinya dan sebagai penyelamat dirinya sendiri. Hubungan perempuan dan alam yang sangat dekat, secara tidak langsung diposisikan sebagai penyelamat dirinya sendiri. Hal demikian dikarenakan legitimasi wacana yang menyatakan bahwa bumi adalah Ibu. Dari berbagai alasan mengapa perempuan menginginkan anak dari darah daging mereka sendiri, salah satunya adalah adanya keinginan untuk merasakan kreativitas dan produktivitas tubuh mereka sendiri secara alamiah, untuk merasakan kekuatan yang hidup di dalam tubuh mereka sendiri yang mampu menembus alam (Shiva dan Mies, 2015: 160).

Di pihak lain, Suma juga digambarkan membangun kegiatan ekonomi berdasarkan relasi baru, yakni menjaga dan melestarikan alam dalam hal keanekaragamannya serta membangun relasi yang harmonis antara manusia dengan alam dengan cara tidak mengeksploitasi dan menindas perempuan demi membangun kesetaraan gender.

Di pagari rangkaian bunga segar bernuansa pastel yang diselang-selingi anggrek bulan putih, antrum itu disulap menjadi tanaman tropis di tengah mall terbesar di Jakarta Selatan. Kandelar kaca bergantungan di sela-sela ronce melati yang malang melintang menaungi para tamu. Tersebar di lima penjuru botol-botol Kristal ukuran raksasa yang berdiri megah di pahatan balok es bermandi lampu sorot. Satu ditempatkan di jantung antrium sebagai focus utama. Botol parfum berwarna emas pucat bertatah tulisan kanga...

Di pinggir area, Jati berdiri memandangi Suma yang tengah dikerubuti orangorang yang hendak memberi selamat, mewawancara, atau sekedar ingin dekatdekat. Kilat kamera menghujani kerumunan itu (Lestari, 2018: 686).

Kutipan di atas menunjukkan sebuah perpaduan antara kemewahan kota Jakarta dengan pesona alam yang menghiasi atrium mall sebagai simbol modernitas. Tokoh Suma yang dikerubuti pendatang pun menyimbolkan prestasinya sekaligus posisinya yang tidak lagi menjadi objek penindasan, tetapi subjek yang bebas. Ia pun menciptakan sebuah relasi baru dengan laki-laki yang bersifat tidak menindas. Di akhir cerita, Suma dan Jati bersama-sama membangun usaha parfum, mereka saling jatuh cinta dengan pesona masing-masing.

Jati melangkah mendekati kerumunan kilatan kamera tersebut, lalu menarik tangan Suma. Sesaat Suma terkejut dengan betotan yang tiba-tiba, tapi kembali sumringah ketika melihat Jati. ..Ia mengiring Suma menepi ke belakang panggung, membawanya masuk ke bilik kecil yang berfungsi sebagai ruang tunggu sekaligus penyimpanan barang-barang pendukung acara. Sehabis menutup selot pintu, Jati mendekap Suma erat-erat (Lestari, 2018: 695). 
Apa yang ditunjukkan oleh Suma dan Jati di atas menandai visi bahwa tujuan dari kegiatan ekonomi untuk melahirkan dan menghasilkan kembali kehidupan, baik itu kehidupan di alam raya maupun kehidupan manusia yang terjalin antara satu dengan yang lainnya. Kehidupan Suma dan Jati yang sempat diporak-porandakan oleh ambisi ekonomi yang eksploitatif kemudian membaik dengan dibangunnya kegiatan ekonomi didasarkan pada relasi baru yang membangun hubungan harmonis antara manusia non eksploitasi dan menindas perempuan demi membangun kesetaraan gender. Mereka juga menciptakan kembali integritas antara kebudayaan dan kerja sebagaimana yang ditunjukkan dalam usaha parfum yang mereka geluti. Inilah perspektif subsistensi yang diupayakan oleh Vandana Shiva dan Mies dalam ekofeminis social transformative yang mereka rintis.

\section{KESIMPULAN}

Novel Aroma Karsa karya Dewi Lestari merupakan kritik terhadap kapitalismepatriarkis dalam memperlakukan alam dan perempuan. Novel tersebut juga menawarkan sebuah perspektif subsistensi yang dipandang bijak untuk kelangsungan hidup baik manusia maupun alam.

Kritik kapitalisme patriarkis dihadirkan melalui tokoh-tokoh Jati Wesi, Khalil, Ferdi, dan tokoh lainnya yang mengejar untung dengan memupuk modal sebesarbesarnya dengan jalan mengeksploitasi alam dan perempuan. Meskipun mereka melakukan pembibitan terhadap spesies tanaman tertentu, tetapi hal itu dilakukan untuk kepentingan industri.

Perspektif subsistensi yang ditawarkan dalam novel ini bahwa perempuan yang lebih banyak memahami alam dibandingkan laki-laki. Adapun peran perempuan terhadap alam yaitu memanfaatkan alam sebagai kebutuhan tetapi mempunyai langkah-langkah untuk memelihara alam, seperti yang ditunjukkan oleh beberapa tokoh, yaitu Janirah Prayagung, Raras Prayagung, dan Tanaya Suma. Mereka berperan dalam pelestarian lingkungan dengan menunjukkan kegigihannya untuk melindungi alam, mengkampanyekan cinta lingkungan dengan pembudidayaan tanaman langka sejenis anggrek kepada masyarakat, dan berusaha mencegah orang-orang untuk berbuat serakah terhadap alam. Di samping itu mereka menunjukkan perannya sebagai perempuan yang ramah lingkungan dengan memanfaatkan tanaman anggrek sebagai kebutuhan, kesehatan, dan tanpa berlebihan. Perspektif subsistensi juga mengarah pada penciptaan relasi baru yang tidak eksploitatif dan sadar gender, sebagaimana ditunjukkan oleh tokoh Tanaya Suma dan Jati Wesi di akhir cerita. Perspektif subsistensi dalam novel ini lebih menekankan pada pelestarian dan perlindungan alam demi kebutuhan dan kenyamanan bersama dan perempuanlah yang lebih banyak memahami alam dibandingkan laki-laki. 


\section{DAFTAR PUSTAKA}

Anisa, (2018). Representasi Mitologi Gunung Lawu dalam Novel Aroma Karsa Karya Dee Lestari. Gondang: Jurnal Seni dan Budaya, 2(2): 26-39

Azizy, A, (2019). Perempuan Dalam Cengkraman Kapitalisme-Patriarki. https://geotimes.co.id/opini/perempuan-dalam-cengkraman-kapitalismepatriarki.

Evelyn, M., \& Grim, J. A. (2003). Agama Filsafat dan Lingkungan Hidup. Yogyakarta: Kanisius.

Khaldirian, F, (2019). Prostitusi, Masyarakat Patriarki, Dan Kapitalisme. https://geotimes.co.id/opini/perempuan-dalam-cengkraman-kapitalismepatriarki/

Lestari, Dewi (2018). Aroma Karsa. Cetakan I. Yogyakarta: PT Benteng Pustaka.

Mary Evelyn dan John A. Grim (ed), 2003. Agama Filsafat dan Lingkungan Hidup (Terjemahan). hal. 217-219. Yogyakarta: Kanisius.

Rahardjo, (1999). Pengantar Sosiologi Pedesaan dan Pertanian. Yogyakarta: Gadjah Mada University Press

Rasiah, (2014). Representasi Alam dan Perkebunan Amerika Bagian Selatan dalam Novel Gone with The Wind Karya Margareth Mitchel. Prosiding Seminar Bahasa dan Sastra dalam Perspektif Ekologi dan Multikulturalisme. Universitas Negeri Yogyakarta.

Rasiah, (2015). Marsha and The Bear: Edukasi Mengenai Hubungan Manusia, Alam dan Binatang (Tinjauan Ekokritik). Prodising One Day Seminar on Ecology of Language and Literature. Universitas Lambung Mangkurat.

Rasiah, Masri, F.A, Arman, Iman, W,N, (2018). Menanamkan Kesadaran Berlingkungan Melalui Penulisan Ekopuisi : Studi Pada Siswa Sma Negeri 4 Kendari. Prosiding Seminar Nasional Teknologi Terapan Berbasis Kearifan Lokal (Snt2bkl). Hal. 616-123. Universitas Halu Oleo

Shiva, V, dan Mies, M, (2005). Ecofeminis: Perspektif Gerakan Perempuan dan Lingkungan (Diterjemahkan oleh Kelik Ismunanto \& Lilik). Cetakan I. Yogyakarta: IRE Press.

Shiva, V, (1997). Bebas dari Pembangunan Perempuan, Ekologi dan Perjuangan Hidup di India (Diterjemahkan oleh Hira Jhatani). Jakarta; Yayasan Obor. 
Suliantoro, B, W, (2013). Konsep Keadilan Sosial yang Berwawasan Ekologis Menurut Vandana Shiva Kajian dari Perspektif Etika Lingkungan. Yogyakarta: Universitas Atma Jaya Yogyakarta.

Tong, R, P, (2010). Feminisme Thought (Terjemahan). Cetakan V. Yogyakarta: Jalasutra

Wuriyani, E, P, Udasmoro, W, \& Simatupang, L, (2017). Negosiasi Mitos Hubungan Perempuan dengan Alam dalam Teks Opera Batak Perempuan di Pinggir Danau Karya Lena Simanjuntak (Tinjauan Ekofeminisme). Jurnal Lingua, 13 (2): 150-165

Vidiyanti, M. O, (2016). “Membaca Novel Lemah Tanjung Karya Ratna Indraswari Ibrahim: Tinjauan Ekofeminisme Vandana Shiva" dalam Kumpulan Artikel Sastra Hijau dan Ekofemenisme (eds.Wiyatmi, Else liliani, Dwi Budiyanto). Yogyakarta: Jurusan Bahasa dan Sastra Indonesia. Hal. 147-163.

Zucker, K, J, (2019). Adolescents with Gender Dysphoria: Reflections on Some Contemporary Clinical and Research Issues in Journal Archives of Sexual Behavior 48(5). 